\title{
Seminal sıvının fertilizasyondaki rolü
} The rol of seminal fluid in fertilization

\author{
Murat Serkant Ünal'1, Mehmet Caner Özer ${ }^{1}$, Ferhan Hacioğlu Sönmez¹, Gülsen Bayrak², \\ Hatice Oruç Demirbağ
}

\section{öz}

Geçmiş yıllarda erkek infertilitesi araştırmaları sperm odaklıyken, günümüzde seminal sıvının öneminin anlaşılmasıyla birlikte bu konu hakkındaki çalışmalar hız kazanmıştır. Seminal sıvının \%90'ı prostat ve seminal veziküllerden, az miktarı da bulbouretral bezler (Cowper) ve epididimlerden salınan salgılardan oluşur.

Seminal sıvının birçok fonksiyonu vardır. İçerdiği fruktoz ile spermatozoonları besler, antioksidan sistemleriyle oksidatif stres sonucu oluşan reaktif oksijen türlerine (ROS) karşı spermatozoayı korur. Ejekülasyondan sonraki aşamada ise vajinanın antibakteriyel asidik ortamına karşı $(\mathrm{pH}$ 4-4,5) bir izolasyon oluşturur, immün reaksiyonu engeller ve spermatozoonları servikse kadar taşır. Spermatozoanın kapasitasyonunu engelleyen faktörler içererek erken aktivasyonunu önler ve içerdiği progesteron ile fertilize ovumun implantasyonunda rol oynar. Ayrica seminal sıvı spermatozoanın moleküler yapısını koruyarak sperm oosit etkileşiminde rol oynar.

Post-testiküler matürasyon sürecinde kapasitasyon ve akrozom reaksiyonunu tamamlayan spermatozoa dölleme yeteneği kazanır. Oosit ve etrafındaki foliküler hücrelerden salınan kimyasal faktörler, kapasite spermi oosite çeker. Fertilizasyon karmaşı moleküler olaylardan oluşur ve sperm ile oositin birbirleriyle temas etmesiyle başlar, maternal ve paternal kromozomların birleşmesiyle sona erer. Spermatozoa ve oosit kadar seminal plazmanın da iyi kalitede olması, spontan gebelikleri ve intrauterin inseminasyondaki (IUI) başarıyı arttırabilir.

Bu derlemede, semen viskozitesinin ve biyokimyasal içeriğindeki farklılıkların, fertilizasyon ve IUI işlemindeki başarıyı nasıl etkilediği tartışılıp cevaplar aranacaktır.

Anahtar Kelimeler: Spermatozoa, seminal sıvı, semen, fertilizasyon

\section{Gíriș}

Klinik olarak infertilite, bir yıllık korunmasız düzenli ilişkiye rağmen gebe kalamama durumu olarak tanımlanır. ${ }^{[1]}$ İnfertil çiftlerin yaklaşık \%30'unda problem erkekte, \%20'sinde

${ }^{1}$ Denizli Devlet Hastanesi, Infertilite Merkezi, Denizli

${ }^{2}$ Mersin Üniversitesi Tıp Fakültesi, Histoloji ve Embriyoloji Anabilim Dalı, Mersin

Yazışma Adresi / Correspondence:

Uzm. Dr. Murat Serkant Ünal

Denizli Devlet Hastanesi, Denizli - Türkiye

Tel. $\quad$ +902582639311/4073

E-mail: serkantunal72@gmail.com

Gelis / Received: $\quad 06.09 .2017$

Kabul / Accepted: 10.11.2017

\section{ABSTRACT}

The researches on male infertility in the past years were focused on sperm but in these days, the investigations gathered pace with understanding the seminal fluid. $90 \%$ of the seminal fluid consists of prostate and seminal vesicles secretions, and a small amount consists of bulbourethral glands (Cowper) and epididymis secretions.

Seminal fluid has many functions. It includes fructose which is the main source of energy for spermatozoa, and protects spermatozoa against reactive oxygen species (ROS) by using antioxidant systems. After ejaculation, seminal plasma forms an isolation to antibacterial acidic field of vagina $(\mathrm{pH} 4-4.5)$, inhibits immune reaction and transports spermatozoa to the cervix. It contains factors that disrupt the capacitation of spermatozoa to prevent early activation and plays a role in the implantation of the fertilized ovum with progesterone. Also seminal fluid helps in sperm-oocyte interaction by preserving the molecular structure of the spermatozoa.

Spermatozoa gain the ability to fertilize, which complete the capacitation and acrosome reaction, in the process of post-testicular maturation. Chemical signals, secreted by the oocyte and surrounding follicular cells, guide the capacitated sperm. Fertilization is a complex molecular event that begins with the connection between a sperm and an oocyte, and ends with the intermingling of maternal and paternal chromosomes. The good quality of the seminal plasma as well as the spermatozoa and oocyte may increase the success of spontaneous pregnancies and intrauterine insemination.

In this review, it is to be discussed and searched answers for how the differences in semen viscosity and biochemical content affect fertilization and IUI success.

Keywords: Spermatozoa, seminal fluid, semen, fertilization

ise çiftin her ikisinde bulunmaktadır. ${ }^{[2]}$ Erkek infertilitesi birçok faktörden kaynaklanmasına rağmen (konjenital ya da kazanılmış ürogenital bozukluklar, genital sistem enfeksiyonları, varikosel, endokrin bozukluklar, genetik hastaliklar ve immünolojik faktörler) olguların \%40-50'inde sorumlu bir faktör bulunmaz (İdiopatik Erkek İnfertilitesi). ${ }^{[3]}$

İnfertilite tedavilerinde hedef kısa zamanda ve düşük maliyetle sağlıklı bir doğum yaptırmaktır. Hafif erkek faktörü ve idiopatik infertilitesi olan çiftlerde ilk tedavi seçeneği olarak IUI kullanılmaktadır. Bu yöntem yardımcı üreme teknikleri sınıfına alınmamakla birlikte, sıklıkla uygulanır ve gebelik oranlarında siklus başına ortalama \%10-20 arasında başarıya ulaştığı bildirilmiştir. ${ }^{[4]}$ 
Erkek üreme sistemi testisler, genital boşaltım kanalları, aksesuar bezler ve penisten oluşmaktadır. Testislerde spermatogenez sonucu üretilen spermatozoonlar, genital boşaltım kanallarına iletilir. Genital boşaltım kanalları olan epididimis ve duktus deferens salgıları ile aksesuar bezlerden gelen salgılar spermatozoonlarla birleşerek semen oluşturulur.[5] Semen, sellüler ve asellüler olmak üzere iki komponente ayrılır. Sellüler kısım spermatozoonlardan (\%2-5 arası) oluşur. Asellüler komponente ise seminal plazma (SP) adı verilir. $^{[6,7]}$ Seminal plazma, insanda yalnızca spermatozoonların taşınması ve canlılığını sürdürmesini sağlayan bir ortam değildir. Bu sıvı, immünoglobulinler, kemokinler ve sitokinler dahil çok sayıda immün regülatör faktör içerir. $\mathrm{Bu}$ faktörler erkek gametlerine karşı dişinin immün toleransını arttırır ve immün cevabı düzenler. ${ }^{[8]}$

Seminal plazmanın majör proteinleri üç ana gruptan oluşur. Bunlar, protein taşıyan fibronektin tip 2 (Fn-2) modülleri, spermadhezinler ve sisteinden zengin sekretuvar proteinlerdir (CRISPs). ${ }^{[6,9]} \mathrm{Bu}$ proteinlerden spermadhesinler, spermatozoanın plazma membranına bağlanarak membran stabilizasyonunu sağlar. Ayrıca, kapasitasyon ve spermatozoanın zona ile etkileşiminde rol alır. ${ }^{[6]}$

Cinsel birleşme sırasında vajen arka forniksine atılan semenden, likefaksiyon sonrası hareketlenen spermler servikse geçer. Servikse ulaşan spermler ejakülatın \%1'inden azdır. Spermatozoonlar servikste saatlerce, tüm genital kanalda ise birkaç gün canlı kalabilir. Serviks geçilirken hareketsiz ve cansız spermler ile semendeki diğer hücreler temizlenir ve spermatozoonların semenden ayrilarak uterusa ulaşması sağlanır. Uterusa ulaşan spermler, kapasitasyona hazır hale gelir. ${ }^{[2,10,11]}$

Spermatozoanın seminal sıvı içerisindeyken fertilizasyon özelliği yoktur. Çünkü, seminal sıvı spermatozoanın kapasitasyonunu engelleyen faktörler içermektedir. Kapasitasyon, spermatozoanın dişi genital sisteminde fertilizasyon yeteneği kazandığı moleküler ve fizyolojik olayların tümünü kapsayan, servikste başlayıp tuba uterinada tamamlanan ve yaklaşık yedi saat süren bir süreçtir. Kapasitasyonu tamamlamış spermatozoonlar, oosit etrafında bulunan kumulus hücreleri tarafından salgilanan kemoatraktan moleküller ile oosite doğru çekilir. Spermartozoonlar, oositle karşılaştıklarında akrozomal reaksiyon denilen bir sürece daha girer. Ancak kapasitasyon sürecini tamamlamış spermler akrozom reaksiyonu geçirerek zona pellusidayı aşabilir. ${ }^{[2]}$

Bu derlemedeki amacımız, ejekülasyon ile spermatozoanın epididimisten çıktığı andan itibaren servikse ulaşması anına kadar taşınması ve korunmasını sağlayan seminal sıvının özelliklerini tartışmaktır.

\section{SEMINAL BEZLER}

Spermatozoa, testislerdeki seminifer tübüllerde üretilir, epididimlerde depolanır ve aksesuar bezlerden gelen sıvı salgılarla karışarak seyreltilir. Semen ise spermatozoanın konsantre süspansiyonundan oluşturulur. ${ }^{[5,12]}$

Aksesuar bezler; prostat bezi, seminal veziküller ve bulboüretral bezlerden (Cowper bezleri) oluşur. Bu bezlerden salgılanan seminal sıvının fiziksel ve biyokimyasal özellikleri, enfeksiyonlar, çevre kirliliği, ilaçlar, genetik faktörlerden etkilenebilir. ${ }^{[13]}$

Prostat bezi: Erkek üreme sistemindeki en büyük aksesuar cinsiyet bezidir. Epiteli genelde tek katlı prizmatiktir, fakat yer yer tek katlı yassı, kübik ya da bazen yalancı çok katlı yamalar bulundurmaktadır. Prostat bezinin epitelyal hücrelerinden salgılanan ekstrasellüler veziküller bulunmaktadır. Bu veziküllere prostasom adı verilir. Prostasomlar, spermatozoonların kapasitasyon zamanını düzenler, akrozom reaksiyonunu indükler ve sperm motilitesini stimüle eder. Ayrıca, kadın genital sisteminde immün hücrelerle etkileşerek spermatozoonları fagositten korur ve ömürlerini uzatır. ${ }^{[14]}$

Prostat bezi 30-50 kadar tübüloalveolar bezden oluşmaktadır. Bu bezler, içte mukozal, arada submukozal ve esas prostatik bezleri içeren periferik tabaka olmak üzere üç konsantrik tabaka halinde düzenlenmiştir. Prostat bezindeki salgı, ejekülasyon sırasında prostatın fibromusküler dokusunun kasılması ile prostatik üretraya pompalanır. ${ }^{[2,5]}$ Prostat bezi salgısı, seminal sıvının \%20-30'unu oluşturur ve hafif alkalidir ( $\mathrm{pH}: 7,29)$. Salg1 ürünleri; prostat asit fosfataz (PAP), prostat spesifik antijen (PSA), amilaz, sitrik asit, çinko ve fibrinolizindir. ${ }^{[5,14]}$ Semenin likefiye olmas1nı sağlayan proteolitik enzim (serin proteaz olan) PSA'dır. Fibrinolizin ise semeni akışkan hale getirir. ${ }^{[2,5]}$ Semenin kendine özgü kokusunun, prostat salgılarından kaynaklanan sperm oksidasyonu sonucu ortaya çıktığı düşünülmektedir. $^{[15]}$ Semende prostatın normal salgılama kapasitesini göstermek için çinko, sitrik asit ve asit fosfataz analizleri yap1lır. ${ }^{[16]}$

Seminal veziküller: Her bir seminal vezikülün tek katlı kübik epitelden yalancı çok katlı prizmatik epitele doğru değişen bir mukozası vardır. Mukoza primer, sekonder ve tersiyer katlantılar yaparak salgı yüzey alanını arttırır. Seminal vezikül salgısı beyazımsı sarı renkte, visköz bir materyal olup ${ }^{[5]}$, seminal sıvının büyük bir (\%50-70) kısmını oluşturur. Salg1 içerisinde fruktoz, prostaglandin, amino asitler, askorbik asit, basit şekerler ve seminal veziküle özgü proteinler bulunmaktadır. Fruktoz, ejekülasyonla atılan spermin ana enerji kaynağıdır. Ejekülasyon sırasında 
seminal veziküllerin düz kasının kasılması sonucu salgı, ejakülatuar kanal içine boşaltılır ve spermatozoanın üretra dışına atılımı sağlanır.

Seminal veziküllerin sekretuar epitelinden, semenin koagüle olmasına neden olan semenogelin adlı bir protein salgılanır. Spermatozoanın kapasitasyonunu ve seminal koagülumundaki spermin hareketlerini önleyen bu proteinin; Semenogelin I ( $52 \mathrm{kDa}$ ) ve Semenogelin II (71 ve $76 \mathrm{kDa})$ olmak üzere iki çeşidi vardır. Semenogelin, semen sıvısının major bileşenidir ve seminal proteinlerin \%20-40' 1 nı oluşturur. ${ }^{[17]}$ Seminal veziküllerin salgılama fonksiyonunu göstermek için fruktoz ölçümü yapılır. ${ }^{[16]}$

Bulboüretral bezler (Cowper bezleri): Prizmatik epitel ile döşeli bileşik tübüloalveolar bezlerden oluşur ve mukus benzeri bir salgı üretir. Salg1sı, seminal sıvının \%2-5'ini oluşturur. ${ }^{[14]}$ Oldukça bol galaktoz, galaktozamin, galakturonik asit, metilpentoz ve ortalama miktarda sialik asit içerir. Seksüel stimülasyonla birlikte, kayganlaştırıcı fonksiyona sahip sekresyonları, erkek üretrasındaki rezidüe idrarı ve kadındaki asidik vaginal salgıları nötralize eder. Prostat, seminal veziküller ve bulboüretral bezlerin fonksiyonu androjenler tarafindan düzenlenir. ${ }^{[5]}$

\section{SEMENIN FiziKSEL ÖZELLIKLERi}

Normal likefiye olmuş semen örneği, homojen, gri-opalesan bir görünüme sahiptir. Ejakülasyonda atılan ilk semen fraksiyonları esasen spermden zengin prostat sıvisıyken, daha sonraki fraksiyonlar büyük miktarda seminal vezikül sıvısını içerir. Semenin normal hacmi 2-6 mL arasındadır. Yüksek semen hacmi, aksesuar bezlerin aktif inflamasyonlarındaki aktif eksüdasyonu yansıtabilir. Semen pH'ı yaklaşık olarak 7,2'dir. Bu değer, seminal vezikülün alkalen salgısı ile prostat bezinin asidik salgısı arasındaki dengeyi temsil eder. Likefaksiyon genellikle 15 dakika içinde olur, nadiren 60 dakika ve üzerine çıkar. Normal semen, plastik pipetten küçük damlalar şeklinde düşer. Viskozite anormal ise damla 2 cm'den uzun iplikçik oluşturur. ${ }^{[16]}$ Hafif viskozitede damlanın boyu $2-4 \mathrm{~cm}$, orta hiperviskozitede 4-6 $\mathrm{cm}$, şiddetli hiperviskozitede ise $6 \mathrm{~cm}^{\prime}$ den daha fazladır. ${ }^{[13]}$ Visköz semen numunesi, homojen yapışkanlık sergiler ve kıvamı zamanla değişmez. Pipetle alınmaya çalışıldığında kitlesi kendine sıkıca yapışıktır. ${ }^{[16]}$ Seminal sıvı hiperviskozitesinin prevalansı \%12-29 aralığındadır, olası nedenlerin bulunmasına karşın etiyolojisi ve oluşum mekanizması hala aydınlatılamamıştır. ${ }^{[13]}$

\section{SEMINAL BEZLERDEKI FONIKSIYON DEĞișiKLIKLERI}

Seminal bezlerin hipofonksiyonu ve disfonksiyonu, seminal sıvıda kimyasal ve fiziksel değişikliklere neden olarak semenin viskozitesini ve miktarını etkiler. Oksidatif stresle ilişkili ROS üretimi, seminal bezlerin enfeksiyonu ve inflamasyonu, lökospermi, genetik faktörler (kistik fibrozis), sigara içimi ve çevre kirliliği, varikosel, genito-üriner sistem enfeksiyonları gibi faktörler, semen viskozitesinde artışlara yol açabilir. ${ }^{[13]}$ Seminal bezlerdeki bir enfeksiyon, salgılay1c1 epitelde geri dönüşümsüz hasara neden olabilir. Bu hasar sonucu seminal sıvı miktarında azalmalar görülebilir, hatta tedaviden sonra bile salgılar düşük düzeylerde kalabilir. ${ }^{[16]}$

ROS, insan ejakülatında hem spermatozoa hem de lökositler tarafından üretilmektedir. Düşük miktarda ROS üretiminin, fertilizasyon, akrozom reaksiyonu, hiperaktivasyon ve hareket için gerekli olduğu yapılan çalışmalarla gösterilmiştir. ${ }^{[18]}$ Tek bir lökosit, tek bir sperme göre en az 100 kat daha fazla ROS üretebilmektedir. Seminal plazma, serbest radikal antioksidan süpürücülere ve antioksidan enzimlere sahiptir. ${ }^{[16]}$ Böylece, spermatozoayı peroksidasyon reaksiyonundan korur ve spermatozoanın kromatin bütünlüğünü muhafaza eder. ${ }^{[19]}$ Oksidatif stres, spermatozoada DNA fragmantasyonuna neden olur ve bu, erkek infertilitesinin önemli sebeplerinden biridir. ${ }^{[20]}$ Yardımlı üreme için spermin hazırlanması sırasında seminal plazmanın alınması, bu hücreleri oksidatif saldırılara karşı savunmasız bırakabilmektedir. Ayrıca, IUI veya IVF'da sperm hazırlama için santrifüj zamanının uzaması ROS miktarının artmasına neden olmaktadir. ${ }^{[21]}$

Hücrelerin çoğu, enzimatik olan ya da olmayan antioksidan sistemlere sahiptir. Bu savunma mekanizmaları aşıldığında, sperm fonksiyonu bozulmaktadır. Yüksek miktarlarda ROS üretimi, peroksidatif hasar ve sperm fonksiyonunda kayba, hem nükleer hem de mitokondriyal genomlarda DNA hasarına neden olabilmektedir. ${ }^{[16]}$ Spermlerde hareket için ihtiyaç duyulan enerjiyi sağlamak amacıyla, mitokondriler orta alanda yer almaktadır. Mitokondri DNA'sı çekirdek DNA'sına oranla daha gevşek paketlenmiştir ve daha az korunmaktadır. Bu nedenle, mutasyon açısından ROS hasarına daha açıktır. ${ }^{[22]}$ Yüksek ROS seviyeleri, iç ve dış mitokondri zarını parçalar ve kaspazları aktifleyen sitokrom $\mathrm{C}$ proteinlerini harekete geçirip apoptozisi başlatır. İnfertil hastalarda apoptozisin göstergesi olan sitokrom C, kaspaz 3 ve 9'un yüksek seviyeleri ROS tarafindan meydana getirilen sperm hasarını yansıtmaktadır. ${ }^{[18]}$

Artan ROS miktarının, spermatozoa hücre membranında lipid peroksidasyonunu başlattığı gösterilmiştir. Sperm membranındaki doymamış yağ asitlerinin peroksidasyonu, membran akıcılığının kaybolmasına yol açmakta vefertilizasyon esnasında sperm füzyonuna engel olmaktadir. ${ }^{[22]}$ Spermatozoonların membranında, spesifik antijenler (tirozin 
kinaz sp 95, proakrozin, PH-20, PH-30, sp 56, galaktozil transferaz, spermadezinler, progesteron reseptörü) dişında hücre matriks etkileşimini yürüten nonspesifik proteinler olan matriks proteinleri (kollagen, fibronektin, laminin ile birlikte immunoglobulinler, kaderinler, selektinler ve integrinler gibi adezyon molekülleri) bulunmaktadır. ${ }^{[10]}$ ROS üretimi ve degradasyonu arasındaki dengesizlik, sperm membranında peroksidatif hasar oluşmasına neden olur. Bunun sonucu olarak, sperm motilitesinde fonksiyonel bozulmalar meydana gelir. Spermatogenezis ve epididimal matürasyon sürecinde spermatozoa, ROS'a bağlı kromatin ve flagellar protein modifikasyonu içerir. Fakat, ROS miktarı çok artarsa sperm proteinleri de olumsuz olarak etkilenir. ${ }^{[23]}$ Ayrıca, yüksek ROS seviyelerinin sperm motilitesine zarar verdiği deneysel olarak gösterilmiştir. ${ }^{[24]}$ Son yıllarda, sperm membranının fertilizasyonda çok önemli rolü olduğu anlaşılmıştır.

Semen viskozitesi anormalliği olan hiperviskozite, moleküler olarak spermatozoanın kapasitasyon sürecini ve akrozom reaksiyonununu etkiler. Hipervisköz semenlerde, hareketli spermatozoonlar önemli bir oranda düşmüş ve sayıları azalmıştır. ${ }^{[19]}$ Seminal lökosit miktarındaki artışın hiperviskozite nedeni olabileceği gösterilmiştir. Lökospermi ve hiperviskozite arasında istatiksel olarak önemli bir ilişki bulunmuştur. ${ }^{[25]}$ Hiperviskozite, seminal sıvının antioksidan kapasitesini yüksek oranda bozar. Daha önceki çalışmalarda, anormal sperm ve lökosperminin ROS artışına neden olduğu ve bunların spermatozoonlara zarar verdiği ileri sürülmüştür. ${ }^{[26,27]}$ Prospektif çalışmalarda, seminal hiperviskozitenin başarısız in vitro fertilizasyon ve embriyo transferiyle ilişkili olduğu gösterilmiştir. ${ }^{[19]}$

Enfeksiyonlarda, monosit ve makrofajlar büyük miktarda TNF- $\alpha$ ve IL-6 salgılar. Prostatit ve prostato-vesiküliti olan hastalarda artmış oksidatif stres nedeniyle oluşan ROS ürünleri, pro-inflamatuar sitokinler (IL-6 ve TNF- $\alpha$ ), antiinflamatuar sitokin (IL-10) ve seminal lökositlerin, seminal hiperviskozite ile ilişkisi araştırılmış ve aralarında güçlü bir bağ olduğu bulunmuştur. ${ }^{[28]}$ Matalliotakis ve ark.'nın ${ }^{\text {[29] }}$ yaptıkları çalışmada, semen kalitesiyle sitokin seviyelerinin yükselmesi arasında bir ilişki olmadığı ileri sürülmüş, fakat Fraczek ve ark. ${ }^{[30]}$ artan sitokin seviyelerinin semen kalitesini etkilediğini göstermişlerdir.

Seminal sıvı visko-elastisitesinin, epididimal ve yardımcı seks bezlerinin fonksiyonuyla ilişkili olduğu ve sperm motilitesini etkilediği gösterilmiştir. PSA, seminal plazmanın temel proteolitik enzimidir. Prostat bezinden yetersiz salınan PSA, anormal viskoziteye neden olabilir. Hipervisköz semenlerde PSA enzim miktarının az olması, bu enzim ile semen viskozitesi arasında bir ilişkiyi destekler. Bazı çalışmalarda ise seminal veziküllerdeki fonksiyon azlığının hiperviskozite sebebi olduğu ileri sürülmüş, fakat bu görüş farklı çalışmalarla desteklenmemiştir. Koagülumda önemli bir rol oynayan mevcut $S g I$ ve $S g I I$ seviyelerinin güvenilir bir ölçümü olmaması nedeniyle, bu protein değerleri kullanılamamaktadır. Semen visko-elastisitesinin mekanizmasının aydınlatılmasında, seminal sıvı proteolitik aktivitesinin ve semenogelin miktarlarının güvenli bir şekilde ölçülebilmesi önemli olabilir. ${ }^{[31]}$

Hiperviskozitenin fertilizasyona etki mekanizması hala tam olarak aydınlatılamamıştır. Çoğunlukla, hiperviskozite prostat ve seminal vezikül fonksiyon bozukluğuyla ilişkilidir. Fakat, hiperviskozite aksesuar seks bezleri fonksiyonu normal olan erkeklerde de yaygın olarak görülür. Son zamanlarda kallikrein-ilişkili peptidaz (KLKs) denilen bir tip proteaz bulunmuştur ve bu peptidaz, değişik semen örneklerinde farklı miktarlarda eksprese edilmektedir. Seminal plazma KLKs ekspresyon miktarı ile likefaksiyon ve viskozite arasında bir ilişki bulunmuştur. ${ }^{[13]}$

Hipervisköz semende fruktoz ve fosfor azalır. Ayrıca, çinko miktarı da düşüktür. Yüksek viskoziteli semen örneklerinde her bir spermin ATP içeriği normal semenlere göre artar. Çünkü, spermatozoonların hareketleri bozulur ve hipervisköz semen ATP tüketemez. Spermatozoonlar, enerji kaynaklarını glikolizden, daha az olarak da mitokondriler vasıtasıyla oksidatif fosforilasyondan sağlar. ${ }^{[32]}$ Hipervisköz semende sperm kromatin bütünlügü normal visköz semenlere göre düşüktür. Semen hiperviskozitesi in vitro şartlarda, hem klasik olarak hem de son zamanlarda gelişen yöntemlerle başarılı şekilde tedavi edilmektedir. Yapışıklığı gidermek için semen enjektörlere bağlı künt iğnelerden geçirilir ve normal semen likefaksiyon görünümü elde edilmeye çalışılır. Bu mekanik yöntemler hiperviskoziteyi tamamen çözmez. Proteoliz için $\alpha$-kimotripsin, mukolitik ajan olarak $\alpha$-amilaz, dithiothreitol ve pankreatik dornase kullanılır. Hiperviskozitenin kaynağı enfeksiyon ve lökospermi ise anti-inflamatuar ajanlar ve antibiyotikler kullanılabilir. ${ }^{[13]}$

Sperm üretimi ergenlik çağında başlar. Bu yüzden, bunlar immün sistem tarafından yabancı protein olarak tanınabilir. Testislerde, spermatozoonlar sertoli hücrelerinin sıkı bağlantıları ile dolaşımdaki immünoglobulinlerden korunur. Spermler, erkek üreme kanalının lümeninde bulundukları sürece immün sistemden ayrılır ve yüzeylerindeki antijenlere karşı antikor oluşmaz. Kan-testis bariyeri denen bu engel kırılacak olursa immün tepki başlayabilir. Antikor yapımını başlatan üreme sistemindeki bu bariyerin bozulmasına, vazektomi, varikosel tamiri, testis biyopsisi, torsiyon, darbe ve enfeksiyonlar neden olabilir. Antikorlar, 
özellikle prostat ve seminal vezikül sıvıları içine salgılanır. Boşalma sırasında sperm ile temas edip, onların kümelenmelerine neden olabilir. Bağlanma seviyesinin $\% 50$ veya fazlası, klinik olarak önemli kabul edilir. ${ }^{[5,12]}$ Ayrıca nadir görülse de, seminal plazmaya karşı dişide hipersensivite (içerdiği PSA gibi allerjik proteinlerden dolayı) gelişebilir ve in vitro fertilizasyon için sperm hazırlama, densentizasyon için alternatif olabilir. ${ }^{[33]}$

Seminal plazmada bulunan çeşitli sitokinlerin (IL-1, IL-2 ve TNF- $\alpha$ ) konsantrasyonlarının artışı, kötü semen kalitesi ve erkek infertilitesiyle ilişkili bulunmuştur. ${ }^{[34-37]}$ Sitokinlerin TGF ailesi (TGF- $\alpha$ ve $\beta$ ), Leydig ve seminifer tübüllerin gelişimiyle ilişkilidir. ${ }^{[6,38]} \mathrm{TGF}-\alpha 1$, insan testisinde seminifer tübüllerin fibrozisiyle yani spermatogenezis bozukluğuyla ilişkili bulunmuştur. ${ }^{[36]}$

Ayrica son zamanlarda, ADAM2 (a disintegrin and metalloprotease), KRAP (ki-ras-induced actin-interacting protein), ACRV1 (acrosomal vesicle protein 1), SPACA1 (sperm acrosome associated 1), SPAM1 (sperm adhesion molecule 1) gibi sperm antijenlerinin fertilizasyondaki önemleri anlaşılmış ve bu, daha birçok araştırmaya konu olmuştur. ${ }^{[39-43]}$ Bunların bir bölümü seminal sıvıyla etkileşim halindedir.

\section{SONUC}

Klinikte genel olarak, seminal sıvının fiziksel özelliklerine bakılır. Semenin viskozite değişikliklerinde seminal sıvının biyokimyasal bileşimi değişir. Fakat, tamamen olağan fiziki görünüme sahip ve likefiye olan seminal sıvının da biyokimyasal içeriği normal değerlerden farklı olabilir. Bu iki durumun da spermin moleküler yapısını ve antijenlerini, oosit ile olan etkileşimini, parakrin ve endokrin faktörlerle iletişimini sağlayan reseptörlerini nasıl etkilediği hala tam olarak çözülememiştir. Ayrıca, fiziksel ve biyokimyasal özellikleri normal olmayan semen, kapasitasyon ve akrozom reaksiyonu süreçlerini de etkileyerek moleküler mekanizmayı ve sinyal yollarını bozabilir.

İçindeki birçok maddenin bilinmesine rağmen, seminal sıvının içeriği tamamen keşfedilmemiştir. Bunun yanın$\mathrm{da}$, seminal bezlerin hipofonksiyonu ve disfonksiyonunda, seminal sıvının hacminin artması veya azalması içerdiği maddelerin konsantrasyonlarını değiştirerek fertilizasyonu etkileyebilir. Seminal sıvıdaki tüm bu değişiklikler, idiopatik erkek infertilitesinin de muhtemel nedenlerinden biri olabilir.

IUI işlemi öncesinde, hipervisköz semenin akışkanlığı arttırılabilir. Fakat, muhtemelen moleküler yapısı değişmiş veya mikroçevresi yüzünden fonksiyonları etkilenmiş olan spermatozoa kapasitasyon sürecini, hiperaktivasyon ve akrozom reaksiyonunu tamamlamada yetersiz kalabilir. Bundan dolayı, IUI işlemi öncesi spermatozoonların normal biyokimyasal içeriğe sahip olmayan seminal sıvıdan mümkün olduğu kadar kısa sürede ayrılması başarıyı arttırabilir. Böylece, semendeki yapışıklıkların giderilmesi başta olmak üzere, doku artıkları, antikorlar, lökositler, ağır metaller ve ilaçlar uzaklaştırılmış olur. Ayrıca, kadın genital kanalındaki sekresyonlar ve fertil erkeklerdeki normal seminal sıvılardaki bileşimler göz önüne alınarak geliştirilecek olan yıkama solüsyonlarının bu semen örneklerinde kullanılması, spermatozoanın oositi fertilize etme yeteneği kazanmasına yardımcı olabilir.

Semen kalitesi, normal spermatozoa üretimi yanında seminal bezlerin fonksiyonlarılla ilişkilidir. İnfertil bir çifte yaklaşımda erkeğe ait bir faktörün araştırılmasında, androloji laboratuarında yapılan semen analizlerinde, genel olarak spermatozoanın sayısına, motilitesine ve morfolojisine bakılır. Spermiograma ve bezlerin bilinen fonksiyon testlerine ilaveten, ileride semenogelin, prostasome, PSA ve KLKs miktarlarının ölçülebilmesi, içeriğin anlaşılabilmesi için yararlı olabilir. Seminal sıvıyla ilgili patolojilerin bir an önce tespit edilip tedaviye başlanması için bu testlerin geliştirilmesi ve kullanılması, olası zaman kayıplarını önleyecektir. Bu gelişmeler için ileri çalışmalara ihtiyaç vardır.

\section{Hakem Değerlendirmesi}

Dış bağımsız

\section{Çıkar Çatışması}

Yazarlar çıkar ilişkisi olmadığını beyan etmişlerdir.

\section{Peer-review}

Externally peer-reviewed.

Conflict of Interest

No conflict of interest was declared by the authors.

\section{KAYNAKLAR}

1. Bieniek JM, Drabovich AP, Lo KC. Seminal biomarkers for the evaluation of male infertility. Asian J Androl 2016;18:426-33. doi: 10.4103/1008-682X.175781

2. Delilbaşı L, Ed. Klinik Embriyoloji Uygulamaları Atlası. Ankara: Büyükharf Tıp Yayınları; 2010. p.37-171.

3. EAU Cep kılavuzları. Erkek infertilitesi. İstanbul: Türk Üroloji Derneği; 2014. p.166-88.

4. Şahin G, Tavmergen E. İntrauterin İnseminasyonda Başarıyı Artırmanın Yolları. Türkiye Klinikleri, J Gynecol Obs Special Topics 2012;5:21-9.

5. Ross MH, Pawlina W. Histoloji Konu Anlatımı ve Atlas. Baykal B, Çev. ed. Ankara: Palme Yayıncılık; 2014. p.784-830.

6. Rodriguez-Martinez H, Kvist U, Ernerudh J, Sanz L, Calvete JJ. Seminal plasma proteins: what role do they play? Am J Reprod Immunol 2011;66 Suppl 1:11-22. doi: 10.1111/j.16000897.2011.01033.x 
7. Vitku J, Kolatorova L, Hampl R. Occurence and reproductive roles of hormones in seminal plasma. Basic Clin Androl 2017;27:19. doi: 10.1186/s12610-017-0062-y

8. Soucek K, Slabakova E, Ovesna P, Malenovska A, Kozubik A, Hampl A. Growth/differentiation factor-15 is an abundant cytokine in human seminal plasma. Hum Reprod 2010;25:296271. doi: 10.1093/humrep/deq264

9. Kelly VC, Kuy S, Palmer DJ, Xu Z, Davis SR, Cooper GJ. Characterization of bovine seminal plasma by proteomics. Proteomics 2006;6:5826-33. doi: 10.1002/pmic.200500830

10. Zülfikaroğlu G, Özgür H, Polat S. Molecular aspects of capacitation. Archives Medical Review Journal 2010;19(1):12-24.

11. Gedikli S, Özbek E, Demirci T. Fertilizasyonun moleküler temeli. Van Tip Dergisi 2013;20:294-301.

12. Gardner DK, Weissman A, Howles CM, Shoham Z. Yardımla Üreme Teknikleri Temel Kitabı, Laboratuvar ve Klinik Görüşler, 2. Baskı. İrez T, Arda O, Kaleli S, Çev. Ed. İstanbul: Nobel Tip Kitabevleri; 2010. p.65-115.

13. Du Plessis SS, Gokul S, Agarwal A. Semen hyperviscosity: causes, consequences and cures. Front Biosci (Elite Ed) 2013;5:224-31.

14. Aalberts M, Stout TA, Stoorvogel W. Prostasomes: extra vesicles from the prostate. Reproduction 2014;147:R1-14. doi: 10.1530/ REP-13-0358

15. Tapısız ÖL, Altınbaş ŞK, Abike F, Göktolga Ü. Jinekolog gözü ile semen analizi ve son gelişmeler. J Turk Soc Obstet Gynecol 2012;9:25-31. doi: 10.5505/tjod.2012.60476

16. WHO Laboratuvar El Kitabı, 5. Baskı. Kadıŏlu A, Çev. ed. Türk Üroloji Derneği. İstanbul: Nobel Tip Kitabevleri; 2011. p.1-271.

17. Esfandiari N, de Lamirande E, Gukturk A, et al. Seminal hyperviscosity is not associated with semenogelin degradation or sperm deoxyribonucleic acid damage: a prospective study of infertile couples. Fertil Steril 2014;101:1599-603. doi: 10.1016/j. fertnstert.2014.02.045

18. Demirtaş A, Üntan İ. Seminal sıvı ve spermde stres ve antioksidanlar. Turk Urol Sem 2011;2:24-30.

19. Esfandiari N, Burjaq H, Gotlieb L, Casper RF. Seminal hyperviscosity is associated with poor outcome of in vitro fertilization and embryo transfer: a prospective study. Fertil Steril 2008;90:1739-43. doi: 10.1016/j.fertnstert.2007.09.032

20. Wright C, Milne S, Leeson H. Sperm DNA damaged caused by oxidative stress: modifiable clinical, lifestyle and nutritional factors in male infertility. Reprod Biomed Online 2014;28:684-703. doi: 10.1016/j.rbmo.2014.02.004

21. Shekarriz M, Dewire DM, Thomas AJ Jr, Agarwal A. A method of human semen centrifugation to minimize the iatrogenic sperm injuries caused by reactive oxygen species. Eur Urol 1995;28(1):315.

22. Elder K, Dale B. In-vitro fertilizasyon, 3. Baskı. İrez T, Çev. Ed. İstanbul: Nobel Tip Kitabevleri; 2013. p.1-108.

23. O'Flaherty C, Matsushita-Fournier D. Reactive oxygen species and protein modifications in spermatozoa. Biol Reprod 2017;97:57785. doi: $10.1093 /$ biolre/iox 104

24. Siciliano L, Tarantino P, Longobardi F, Rago V, De Stefano C, Carpino A. Impaired seminal antioxidant capacity in human semen with hyperviscosity or oligoasthenozoospermia. J Androl 2001;22:798-803.

25. Flint M, du Plessis SS, Menkveld R. Revisiting the assessment of semen viscosity and its relationship to leucocytospermia. Andrologia 2014;46:837-41. doi: 10.1111/and.12157

26. Wolff H, Politch JA, Martinez A, Haimovici F, Hill JA, Anderson DJ. Leukocytospermia is associated with poor semen quality. Fertil Steril 1990;53:528-36.
27. Fedder J. Nonsperm cells in human semen: with special reference to seminal leukocytes and their possible influence on fertility. Arch Androl 1996;36:41-65.

28. Castiglione R, Salemi M, Vicari LO, Vicari E. Relationship of semen hyperviscosity with IL-6, TNF-a, IL-10 and ROS production in seminal plasma of infertile patients with prostatitis and prostato-vesiculitis. Andrologia 2014;46:1148-55. doi: 10.1111/and.12207

29. Matalliotakis I, Arici A, Goumenou A, Koumantakis G, Selam B, Matalliotakis G, Koumantakis E. Distinct expression pattern of cytokines in semen of men with genital infection and oligo-teratoasthenozoospermia. Am J Reprod Immunol 2002;48:170-5.

30. Fraczek M, Kurpisz M. Inflammatory mediators exert toxic effects of oxidative stress on human spermatozoa. J Androl 2007;28:32533. doi: 10.2164/jandrol.106.001149

31. ELzanaty S, Malm J, Giwercman A. Visco-elasticity of seminal fluid in relation to the epididymal and accessory sex gland function and its impact on sperm motility. Int J Androl 2004;27:94-100. doi: 10.1046/j.1365-2605.2003.00455.x

32. du Plessis SS, Agarwal A, Mohanty G, van der Linde M. Oxidative phosphorylation versus glycolysis: what fuel do spermatozoa use? Asian J Androl 2015;17:230-235. doi: 10.4103/1008682X.135123

33. Moi L, Salvade I, Ribi C. Allergy to human seminal plasma. Rev Med Suiesse 2017;13:748-53.

34. Naz RK, Kaplan P. Increased levels of interleukin-6 in seminal plasma of infertile men. J Androl 1994;15:220-7.

35. Gruschwitz MS, Brezinschek R, Brezinschek HP. Cytokine levels in the seminal plasma of infertile males. J Androl 1996;17:158-63.

36. Politch JA, Tucker L, Bowman FP, Anderson DJ. Concentrations and significance of cytokines and other immunologic factors in semen of healthy fertile men. Hum Reprod 2007;22:2928-35. doi: 10.1093/humrep/dem281

37. Dousset B, Hussenet F, Daudin M, Bujan L, Foliguet B, Nabet P. Seminal cytokine concentrations (IL-1beta, IL-2, IL-6, sR IL-2, sR IL-6), semen parameters and blood hormonal status in male infertility. Hum Reprod 1997;12:1476-9.

38. Hedger MP, Meinhardt A. Cytokines and the immune-testicular axis. J Reprod Immunol 2003;58:1-26.

39. Vidaeus CM, von Kapp-Herr C, Golden WL, Eddy RL, Shows TB, Herr JC. Human fertilin beta: identification, characterization, and chromosomal mapping of an ADAM gene family member. Mol Reprod Dev 1997;46:363-9. doi: 10.1002/(SICI) 10982795(199703)46:3<363::AID-MRD15>3.0.CO;2-\#

40. Gmachl M, Sagan S, Ketter $S$ and Kreil G. The human sperm protein PH-20 has hyaluronidase activity. FEBS Lett 1993;336:545-8.

41. Diekman AB, Norton EJ, Westbrook VA, Klotz KL, NaabyHansen S, Herr JC. Anti-sperm antibodies from infertile patients and their cognate sperm antigens: a review. Identity between SAGA-1, the H6-3C4 antigen and CD52. Am J Reprod Immunol 2000;43:134-43.

42. Inokuchi J, Komiya M, Baba I, Naito S, Sasazuki T, Shirasawa S. Deregulated expression of KRAP, a novel gene encoding actininteracting protein, in human colon cancer cells. J Hum Genet 2004;49:46-52. doi: 10.1007/s10038-003-0106-3

43. Wright RM, John E, Klotz K, Flickinger CJ, Herr JC. Cloning and sequencing of cDNA coding for the human intra-acrosomal antigen SP-10. Biol Reprod 1990;42:693-701. 